\title{
PENGARUH PENGGUNAAN MEDIA PEMBELAJARAN POWER POINT TERHADAP MIINAT DAN KEMAMPUAN MEMBACA SISWA PADA MATA PELAJARAN BAHASA INDONESIA KELAS IV
}

\author{
Nirmawati, Tarman Andi Arief \\ Pendidikan Guru Sekolah Dasar, Fakultas Keguruan dan Ilmu Pendidikan \\ Universitas Muhammadiyah Makassar \\ Nirma.syamh@gmail.com
}

\begin{abstract}
ABSTRAK
Jenis Penelitian ini adalah pra-eksperimen atau pre- experiment dengan menggunakan desain penelitian One-Grup Pretest-Posttest Design dan menggunakan pendekatan kualitatif. Terdapat 3 variabel dalam penelitian ini yaitu variabel bebas berupa media pembelajaran power point dan variabel terikat berupa minat belajar dan kemampuan mempaca siswa.Penelitian ini bertujuan untuk mengetahui apakah media pembelajaran power point berpengaruh terhadap minat dan kemampuan membaca siswa SDN 03 Ele Kabupaten Barru. Populasi dari penelitian ini yaitu seluruh siswa kelas IV SDN 03 Ele sebanyak 13 siswa. Sampel dalam penelitian ini yaitu murid kelas IV sebanyak 13 siswa dengan teknik pengambilan sampel total sampling.Hasil penelitian ini menunjukkan bahwa penggunaan media pembelajaran power point berpengaruh terhadap minat dan kemampuan membaca siswa kelas IV SDN 03 Ele Kabupaten Barru. hal ini dibuktikan dari hail observasi minat belajar sebesar 86, $67 \%$. Statistik inferensial dengan menggunakan rumus uji-t, diperoleh nilai $t_{\text {hitung }}$ dengan nilai 5,94 lebih besar dari $t_{\text {tabel }}$ dengan nilai 2,178 pada taraf signifikan 5\%. Hal ini menunjukkan bahwa hipotesis nol ditolak dan hipotesis alternative diterima.
\end{abstract}

Kata Kunci : Media Pembelajaran Power Point, Minat Belajar, dan Kemampuan Membaca Siswa.

Abstract: This type of research is a pre-experiment or pre- experiment using the Pretest-Posttest Design One-Group research design and using a qualitative approach. There are 3 variables in this research that is independent variables in the form of learning media power point and dependent variable in the form of interest in learning and students' reading ability. This research is aimed to find out whether the power point learning media has an effect on the interest and reading ability of SDN 03 Ele of Barru. The population of this study is all students of grade IV SDN 03 Ele as many as 13 students. The sample in this study is the fourth graders of 13 students with total sampling sampling technique. The results of this study indicate that the use of power point learning media affect the interest and ability to read grade IV students SDN 03 Ele Barru District. this is evidenced from hail observation interest in learning amounted to $86,67 \%$. Inferential statistics using the $t$ test formula, obtained tcount value with a value of 5.94 is greater than ttable with a value of 2.178 at a significant level of 5\%. This shows that the null hypothesis is rejected and the alternative hypothesis is accepted.

Keywords: Power Point Learning Media, Interest in Learning, and Student Reading Ability. 


\section{PENDAHULUAN}

Kemajuan suatu bangsa dapat dilihat dari tingkat pendidikannya. Semakin tinggi tingkat pendidikan maka suatu bangsa akan menuju kearah kesejahteraan hidup. Semakin tinggi usaha dalam menempuh pendidikan maka hasil yang didapat juga semakin memuaskan, yang mana telah kita ketahui bahwa tujuan pendidikan adalah untuk mencerdaskan kehidupan bangsa, meningkatkan ketaqwaan terhadap Tuhan YME dan membentuk kepribadian. Dalam hal ini, tentu saja diperlukan adanya pendidik yang professional terutama guru-guru di sekolah dasar dan menengah dan dosen di perguruan tinggi (Khoirumattin 2013:1).

Dengan kemajuan zaman dan tantangannya yang makin pesat sekarang ini, guru idealnya terus belajar, kreatif dalam mengembangkan diri, serta terus menerus menyesuaikan pengetahuan dan cara mengajar mereka dengan penemuan baru dalam dunia pendidikan, psikologi dan ilmu pengetahuan. Dalam proses pendidikan pada umumnya, dan pembelajaran pada khususnya sering muncul beragam masalah sehingga seorang guru sangat memerlukan beraneka ragam pengetahuan yang mendukung kegiatan pendidikan termasuk kegiatan pembelajaran dalam kelas. Guru diharapkan dapat menciptakan situasi belajar sehingga mampu memberikan pemahaman siswa dalam menerima pelajaran yang diberikan oleh guru.

Penggunaan media pembelajaran tentunya juga sebagai pendorong keberhasilan transfer of knowledge antara guru dan murid. Penggunaan media pembelajaran merupakan komponen penting dalam proses pembelajaran di sekolah. Dalam penggunaan media pembelajaran akan memberikan bantuan kepada guru dalam menyampaikan materi dan murid dalam memahami pembelajaran yang sedang berlangsung. Sehingga proses belajar menjadi kondusif dan diharapkan menghasilkan prestasi yang meningkat dari pembelajaran tersebut. Penggunaan media pembelajaran juga menarik minat siswa karena dianggap menyenangkan dan mengurangi rasa bosan. Media merupakan alat saluran komunikasi antara guru dan siswa. Penggunaan media dapat menjadikan pembelajaran lebih terarah sehingga siswa dapat lebih fokus 
dalam menerima pelajaran. Namun penggunaan media seringkali diabaikan oleh guru. Menggunakan media pembelajaran dianggap repot dan mengambil banyak waktu untuk membuatnya. Akhirnya guru hanya menggunakan buku pelajaran seadanya.

Sejalan dengan itu, meluasnya kemajuan bidang komunikasi dan teknologi serta tingginya dinamika dalam dunia pendidikan semakin meluas pula tuntutan dan peluang penggunaan media media yang lebih maju dan bervariasi di dalam proses pembelajaran. Teknologi komputer menawarkan berbagai kemungkinan dan kemudahan menghasilkan dan mengolah audio-visual sehingga pembuatan media pembelajaran yang lebih maju dan variatif dapat dilakukan. Micrsoft mengembangkan salah satu program (software) yang dapat digunakan sebagai perangkat untuk mempresentasikan materi kepada audiens, termasuk di dalam proses pembelajaran di sekolah, yakni Microsoft Power Point.

$$
\text { Triwahyuni (2004:2) power }
$$

point menawarkan kemudahankemudahan dalam membuat bahan presentasi yang berbentuk elektronik.
Pada setiap halaman presentasi (slide), dapat disisipkan komponen-komponen multimedia yang meliputi teks, grafik, gambar, foto, suara, film. Dengan menggunakan fitur-fitur yang disediakan power point, presentasi akan lebih hidup dan lebih mengesankan. Dengan penggunaan media pembelajaran power point membuat audience akan lebih terfokus pada media yang ditampilkan sehingga akan dapat meningkatkan minat belajar yang diharapkan mampu meningkatkan hasil belajar terutama pada kemampuan membaca siswa.

Penelitian ini ditujukan kepada siswa kelas IV, karena menurut penulis siswa kelas IV sudah mulai dapat memaknai suatu bacaan yang diberikan. Dalam observasi yang telah dilakukan, hasil belajar mata pelajaran Bahasa Indonesia siswa kelas IV SD Negeri 03 Ele Kabupaten Barru masih terdapat siswa yang memperoleh nilai di bawah KKM. Ditunjukkan pada data hasil tes semester gasal bulan Desember 2016 nilai rata-rata siswa kelas IV mata pelajaran Bahasa Indonesia masih di bawah 65. Ada beberapa faktor penyebabnya yaitu guru sebagai tenaga pengajar dalam melakukan proses pembelajaran dominan 
menggunakan metode ceramah sehingga belum memaksimalkan fasilitas-fasilitas yang ada serta siswa jenuh dan bosan dalam menerima pelajaran yang diberikan oleh gurunya. Mata Pelajaran Bahasa Indonesia menuntut siswa memahami materi melalui teori-teori yang disediakan sehingga ketika pembelajaran berlangsung siswa akan kesulitan untuk menangkap informasi mengenai pembahasan materi yang disampaikan oleh guru karena siswa hanya diberikan metode ceramah oleh guru.

Berdasarkan uraian di atas rumusan masalah dalam penelitian ini adalah (1) Apakah penggunaan media pembelajaran power point berpengaruh terhadap minat belajar siswa kelas IV SD Negeri 03 Ele Kabupaten Barru pada mata pelajaran Bahasa Indonesia?, (2) Apakah penggunaan media pembelajaran power point berpengaruh terhadap kemampuan membaca siswa kelas IV SD Negeri 03 Ele Kabupaten Barru pada mata pelajaran Bahasa Indonesia? (3) Apakah penggunaan media pembelajaran power point berpengaruh terhadap minat dan kemampuan membaca siswa kelas IV SD
Negeri 03 Ele Kabupaten Barru pada mata pelajaran Bahasa Indonesia?.

Tujuan penelitian ini adalah (1) Untuk mengetahui pengaruh penggunaan media pembelajaran power point terhadap minat belajar siswa kelas IV SD Negeri 03 Ele Kabupaten Barru pada mata pelajaran Bahasa Indonesia. (2) Untuk mengetahui pengaruh penggunaan media pembelajaran power point terhadap kemampuan membaca siswa kelas IV SD Negeri 03 Ele Kabupaten Barru pada mata pelajaran Bahasa Indonesia. (3) Untuk mengetahui pengaruh penggunaan media pembelajaran power point terhadap minat dan kemampuan membaca siswa kelas IV SD Negeri 03 Ele Kabupaten Barru pada mata pelajaran Bahasa Indonesia.

\section{METODE PENELITIAN}

Jenis penelitian ini adalah penelitian eksperimen, yaitu metode penelitian yang digunakan untuk mencari pengaruh perlakuan tertentu terhadap yang lain dalam kondisi yang terkendalikan (Sugiyono 2006: 72). Menurut Gay (dalam Emzir 2007: 63) Penelitian eksperimen merupakan satu-satunya metode penelitian yang dapat menguji secara benar hipotesis menyangkut hubungan 
kausal (sebab akibat). Variabel dalam penelitian yang terkait ada dua yaitu variabel bebas dan variable terikat. Dalam suatu penelitian variable harus diklasifikasikan dengan jelas agar tidak terjadi kesalahan dalam pengujian hipotesis. Variabel bebas dalam penelitian ini adalah media pembelajaran power point yang diberi symbol $(X)$. Variabel terikat dalam penelitian ini adalah minat belajar siswa dan kemampuan membaca siswa $\left(Y_{1}\right.$ dan $\left.Y_{2}\right)$

Populasi dalam penelitian ini adalah seluruh siswa kelas IV SDN 03 Ele yang berjumlah 13 siswa. Teknik pengambilan sampel dalam penelitian ini adalah total sampling. Total sampling adalah teknik pengambilang sampel dimana jumlah sampel sama dengan populasi. Adapun sampel dari penelitian ini adalah siswa kelas IV SDN 03 Ele berjumlah 13 siswa. Instrumen yang digunakan untuk mengumpulkan data dalam penelitian ini adalah lembar observasi dan tes hasil belajar. Untuk menganalisis data yang diperoleh dari hasil penelitian akan digunakan analisis statistik deskriptif dan inferensial.. Pengujian perbedaan nilai hanya dilakukan terhadap rata-rata kedua nilai saja dan untuk keperluan itu digunakan teknik yang disebut dengan uji-t (t-test). Dengan demikian langkah-langkah analisis data eksperimen dengan model eksperimen One Group Pretest Posttest Design adalah sebagai berikut:

\section{HASIL PENELITIAN DAN PEMBAHASAN}

Berdasarkan hasil observasi yang telah dilakukan maka minat belajar siswa dapat dilihat pada tabel berikut :

Tabel 1 Perolehan Skor Lembar

Observasi Minat Belajar Siswa

\begin{tabular}{|c|c|c|}
\hline$X$ & $F$ & X.F \\
\hline 20 & 1 & 20 \\
\hline 21 & 1 & 21 \\
\hline 25 & 1 & 25 \\
\hline 26 & 3 & 78 \\
\hline 27 & 3 & 81 \\
\hline 28 & 2 & 56 \\
\hline 29 & 2 & 58 \\
\hline \multicolumn{2}{|c|}{ Total } & 339 \\
\hline
\end{tabular}

Selanjutnya untuk mencari rata-rata nilai minat belajar pada lembar observasi menggunakan rumus :

$$
\begin{aligned}
R M B S & =\frac{\sum \mathrm{MBS}}{n} \\
R M B S & =\frac{339}{13} \\
& =26,07
\end{aligned}
$$


Adapun persentase didapatkan dengan rumus nilai rata-rata

$$
\begin{aligned}
\mathrm{P} & =\frac{f}{N} \times 100 \% \\
\mathrm{P} & =\frac{26,07}{30} \times 100 \% \\
& =87,67 \%
\end{aligned}
$$

Berdasarkan hasil penelitian yang dilakukan oleh peneliti di SDN 03 Ele, Kabupaten Barru. Mulai tanggal 17 Juli-22 Juli 2017, maka diperoleh data-data yang dikumpulkan melalui instrument tes untuk dapat mengetahui hasil belajar murid kelas IV SDN 03 Ele.

Untuk mencari mean (rata-rata) nilai pre-test siswa kelas IV SDN 03 Ele, Kabupaten Barru dapat dilihat melalui tabel berikut :

Tabel 2 Perhitungan nilai mean (rata-rata) nilai pre-test

\begin{tabular}{|c|c|c|}
\hline X & F & X.F \\
\hline 40 & 1 & 40 \\
\hline 50 & 4 & 200 \\
\hline 60 & 7 & 420 \\
\hline 70 & 1 & 70 \\
\hline Jumlah & 13 & 730 \\
\hline
\end{tabular}

Dari data di atas, dapat diketahui bahwa nilai dari $\sum f x=730$, sedangkan nilan $\mathrm{N}$ adalah 13 . Oleh karena itu dapat diperoleh mean sebagai berikut:

$$
\bar{x} \quad=\frac{\sum_{i=1}^{k} f x_{i}}{n}
$$

$$
\begin{aligned}
& =\frac{730}{13} \\
& =56,15
\end{aligned}
$$

Dari hasil perhitungan tersebut, maka diperoleh nilai rata-rata dari hasil belajar kemampuan membaca pada mata pelajaran Bahasa Indonesia siswa kelas IV SDN 03 Ele, Kabupaten Barru. sebelum menggunakan media power point adalah 56,15 .

Tabel 3 Tingkat Penguasaan Materi Pre-

Test

\begin{tabular}{|l|l|l|l|l|}
\hline No. & Interval & Frekuensi & $\mathbf{( \% )}$ & $\begin{array}{l}\text { Kategori } \\
\text { hasil } \\
\text { belajar }\end{array}$ \\
\hline 1 & $0-54$ & 5 & $38,46 \%$ & $\begin{array}{l}\text { Sangat } \\
\text { rendah }\end{array}$ \\
\hline 2 & $55-64$ & 7 & $53,84 \%$ & Rendah \\
\hline 3 & $65-74$ & 1 & $7,69 \%$ & Sedang \\
\hline 4 & $75-84$ & 0 & $0 \%$ & Tinggi \\
\hline 5 & $85-100$ & 0 & $0 \%$ & $\begin{array}{l}\text { Sangat } \\
\text { tinggi }\end{array}$ \\
\hline \multicolumn{5}{|c|}{ Jumlah } \\
\hline \multicolumn{5}{|c|}{ Berdasarkan data yang dapat } \\
\hline
\end{tabular}

dilihat pada tabel di atas, maka dapat disimpulkan bahwa hasil belajar murid pada tahap pretest dengan menggunakan instrumen test dikategorikan sangat rendah yaitu 38,4\%, rendah 53,8 \%, sedang 7,69\%, tinggi $0,0 \%$ dan sangat tingggi berada pada presentase 0,0\%. Melihat dari hasil presentase yang ada dapat dikatakan bahwa tingkat kemampuan murid dalam memahami 
serta penguasaan kemampuan membaca tergolong rendah.

Tabel 4 Ketuntasan Hasil Belajar Keterampilan Membaca

\begin{tabular}{|l|l|l|l|}
\hline Skor & Kategorisasi & Frekuensi & Presentase \\
\hline $0-64$ & $\begin{array}{l}\text { Tidak } \\
\text { tuntas }\end{array}$ & 12 & $92,30 \%$ \\
\hline $65-100$ & Tuntas & 1 & $7,6 \%$ \\
\hline Jumlah & & 13 & \\
\hline
\end{tabular}

Apabila Tabel 4 dikaitkan dengan indikator kriteria ketuntasan hasil belajar keterampilan menulis deskripsi murid yang ditentukan oleh peneliti yaitu jika jumlah murid yang mencapai atau melebihi nilai KKM (65) $\geq 75 \%$, sehingga dapat disimpulkan bahwa hasil belajar membacai murid kelas IV SD Negeri 03 ELE, Kec.Tanete Riaja, Kab. Barru belum memenuhi kriteria ketuntasan hasil belajar secara klasikal dimana murid yang tuntas hanya $7,6 \% \leq 92,30 \%$.

Selama penelitian berlangsung terjadi perubahan terhadap kelas setelah diberikan perlakuan. Perubahan tersebut berupa hasil belajar yang datanya diperoleh setelah diberikapost-test. Perubahan tersebut dapat dilihat dari data berikut ini :
Tabel 5 Perhitungan nilai mean (ratarata) nilai post-test

\begin{tabular}{|l|l|l|}
\hline X & F & X.F \\
\hline 60 & 3 & 180 \\
\hline 70 & 2 & 140 \\
\hline 80 & 3 & 240 \\
\hline 90 & 3 & 270 \\
\hline 100 & 2 & 200 \\
\hline Jumlah & 79,23 & 1030 \\
\hline
\end{tabular}

Dari data di atas, dapat diketahui bahwa nilai dari $\Sigma f x=990$, sedangkan nilan $\mathrm{N}$ adalah 13 . Oleh karena itu dapat diperoleh mean sebagai berikut:

$$
\begin{aligned}
\bar{x} & =\frac{\sum_{i=1}^{k} f x_{i}}{n} \\
& =\frac{990}{13} \\
& =76,15
\end{aligned}
$$

Dari hasil perhitungan di atas, maka diperoleh nilai rata-rata dari hasil belajar kemampuan berbicara murid kelas IV SD Negeri Ele yaitu 80 dari skor ideal 100. Adapun di kategorikan pada pedoman Departemen pendidikan dan kebudayaan (Depdikbud), maka keterangan murid dapat dilihat pada tabel berikut

Tabel 6 Tingkat Penguasaan Materi

\section{Post-Test}

\begin{tabular}{|l|l|l|l|l|}
\hline No. & Interval & Frekuensi & Persentase & $\begin{array}{l}\text { Kategori } \\
\text { hasil } \\
\text { belajar }\end{array}$ \\
\hline
\end{tabular}




\begin{tabular}{|r|l|l|l|l|}
\hline 1 & $0-54$ & - & $0,00 \%$ & $\begin{array}{l}\text { Sangat } \\
\text { rendah }\end{array}$ \\
\hline 2 & $55-64$ & 3 & $23.07 \%$ & Rendah \\
\hline 3 & $65-74$ & 2 & $15,38 \%$ & Sedang \\
\hline 4 & $75-84$ & 3 & $23,07 \%$ & Tinggi \\
\hline 5 & $85-100$ & 5 & $38,46 \%$ & $\begin{array}{l}\text { Sangat } \\
\text { tinggi }\end{array}$ \\
\hline \multicolumn{2}{|l|}{ Jumlah } & 13 & $100 \%$ & \\
\hline
\end{tabular}

Berdasarkan data yang dapat dilihat pada tabel di atas, maka dapat disimpulkan bahwa hasil belajar pada tahap post-test dengan menggunakan instrumen test dikategorikan sangat tinggi yaitu 38,46\%, tinggi 23,07\%, sedang $15,38 \%$, rendah $23,07 \%$, dan sangat rendah berada pada presentase 0,00\%. Melihat dari hasil presentase yang ada dapat dikatakan bahwa tingkat kemampuan murid dalam memahami serta penguasaan materi keterampilan membaca tergolong tinggi.

Tabel 7 Ketuntasan Hasil Belajar Keterampilan Membaca

\begin{tabular}{|l|l|l|l|}
\hline Skor & Kategorisasi & Frekuensi & Presentase \\
\hline $0-64$ & $\begin{array}{l}\text { Tidak } \\
\text { tuntas }\end{array}$ & 3 & $23,07 \%$ \\
\hline $65-100$ & Tuntas & 10 & $76,92 \%$ \\
\hline Jumlah & 13 & \\
\hline
\end{tabular}

Apabila Tabel 6 dikaitkan dengan indikator kriteria ketuntasan hasil belajar murid yang ditentukan oleh peneliti yaitu jika jumlah murid yang mencapai atau melebihi nilai KKM (65) $\leq 75 \%$, sehingga dapat disimpulkan bahwa hasil belajar kemampuan membaca siswa kelas IV SDN 03 Ele, Kabupaten Barru telah memenuhi kriteria ketuntasan hasil belajar secara klasikal dimana murid yang tuntas adalah 76,92\%. $\geq 75 \%$. Apabila Tabel 7 dikaitkan dengan indikator kriteria ketuntasan hasil belajar murid yang ditentukan oleh peneliti yaitu jika jumlah murid yang mencapai atau melebihi nilai KKM 65, sehingga dapat disimpulkan bahwa hasil belajar membaca siswa telah memenuhi kriteria ketuntasan hasil belajar secara klasikal dimana murid yang tuntas adalah $76,92 \% . \geq 75 \%$.

Sesuai dengan hipotesis penelitian yakni penggunaan media pembelajaran power point terhadap minat "penggunaan model pembelajaran Teknik Show Not Tell memiliki pengaruh terhadap keterampilan menulis deskripsi murid kelas V SD Negeri Tanetea, Kec.Bajeng, Kab.Gowa" maka teknik yang digunakan untuk menguji hipotesis tersebut adalah teknik statistik inferensial dengan menggunakan uji-t.

Tabel 8 Analisis skor Pre-test dan Post-test

\begin{tabular}{|l|l|l|l|l|}
\hline No & $\mathbf{X 1}$ & $\mathbf{X} 2$ & $\mathbf{d}=\mathbf{X} 2-$ & $\mathbf{d}^{\mathbf{2}}$ \\
\hline
\end{tabular}




\begin{tabular}{|c|c|c|c|c|}
\hline & $\begin{array}{c}\text { (Pre- } \\
\text { test })\end{array}$ & $\begin{array}{c}\text { (Post- } \\
\text { test })\end{array}$ & $\mathbf{X 1}$ & \\
\hline 1 & 50 & 80 & 30 & 900 \\
\hline 2 & 60 & 80 & 20 & 400 \\
\hline 3 & 60 & 60 & 0 & 0 \\
\hline 4 & 50 & 90 & 40 & 1600 \\
\hline 5 & 70 & 90 & 20 & 400 \\
\hline 6 & 60 & 100 & 40 & 1600 \\
\hline 7 & 50 & 60 & 10 & 100 \\
\hline 8 & 50 & 100 & 50 & 2500 \\
\hline 9 & 40 & 70 & 30 & 900 \\
\hline 10 & 60 & 90 & 30 & 900 \\
\hline 11 & 50 & 60 & 10 & 100 \\
\hline 12 & 60 & 70 & 10 & 100 \\
\hline 13 & 60 & 80 & 20 & 400 \\
\hline Ju & & & & 9.900 \\
$\mathbf{m l}$ & 720 & 1.030 & 310 & \\
\hline $\mathbf{a h}$ & & & & \\
\hline
\end{tabular}

Langkah-langkah dalam pengujian hipotesis adalah sebagai berikut :

Mencari harga "Md" dengan menggunakan rumus:

$$
\begin{aligned}
\mathrm{Md} & =\frac{\sum d}{N} \\
& =\frac{310}{13} \\
& =23,84
\end{aligned}
$$

Mencari harga " $\sum X^{2} d$ ” dengan menggunakan rumus:

$$
\begin{aligned}
\sum X^{2} d & =\sum d^{2}-\frac{\left(\sum d\right)^{2}}{N} \\
& =9900-\frac{(310)^{2}}{13} \\
& =9900-\frac{96100}{13} \\
& =9900-7392,307 \\
& =2507,7
\end{aligned}
$$

Menentukan Nilai $t_{\text {Hitung : }}$

$$
\begin{aligned}
\mathrm{t} & =\frac{M d}{\sqrt{\frac{\sum X^{2} d}{N(N-1)}}} \\
\mathrm{t} & =\frac{23,84}{\sqrt{\frac{2507,7}{13(13-1)}}} \\
\mathrm{t} & =\frac{23,84}{\sqrt{\frac{2507,7}{156}}} \\
\mathrm{t} & =\frac{23,84}{\sqrt{16,07}} \\
\mathrm{t} & =\frac{23,84}{4,008} \\
\mathrm{t} & =5.94
\end{aligned}
$$

Untuk mencari $t$ Tabel peneliti menggunakan tabel distribusi $\mathrm{t}$ dengan taraf signifikan $\alpha=0,05$ dan $d . b=N-$ $1=13-1=12$ maka diperoleh $\mathrm{t}_{0,05}=$ 5,94 . Setelah diperoleh $t_{\text {Hitung }}=5,94$ dan $\mathrm{t}_{\text {Tabel }}=2,178$ maka diperoleh $\mathrm{t}_{\text {Hitung }}>$ $t_{\text {Tabel }}$ atau 5,94 $>2,178$. Sehingga dapat disimpulkan bahwa $\mathrm{H}_{0}$ ditolak dan $\mathrm{H}_{1}$ diterima. Ini berarti bahwa Penggunaan media pembelajaran power point berpengaruh terhadap kemampuan membaca siswa kelas IV SD Negeri 03 Ele.

Dari hasil pengelolaan data tersebut dapat dianalisa bahwa penggunaan powerpoint mempunyai pengaruh yang positif terhadap minat belajar Berdasarkan hasil observasi oleh peneliti menunjukkan $84,61 \%$ minat belajar siswa sehingga termasuk dalam kategori tinggi. Hasil minat belajar siswa 
dalam penelitian ini diperoleh melalui lembar observasi minat belajar siswa. Lembar observasi diisi oleh guru melalui pengamatan ketika proses pembelajaran berlangsung. Pada saat pembelajaran berlangsung dengan menggunakan media pembelajaran power point, siswa-siswi terlihat antusias dalam menerima pembelajaran. Siswa memperhatikan media yang ditampilkan dan memperhatikan setiap detail bacaan yang terdapat dalam media power point seperti pengertian pengumuman, contoh pengumuman dan yang lainnya. Siswasiswi tidak mengerjakan sesuatu hal yang lain selain memperhatikan media yang ditampilkan. Siswa juga memahami materi pembelajaran sehingga materi yang sebelumnya tidak dipahami menjadi lebih paham sehingga apabila guru bertanya siswa dengan sigap merespon pertanyaan guru. Hal tersebut menandakan minat belajar siswa meningkat setelah guru menggunakan media pembelajaran power point.

Minat belajar pada siswa merupakan hal yang sangat penting. Karena adanya minat belajar akan menimbulkan siswa untuk lebih menyukai pembelajaran. Oleh karena itu, untuk membangun minat belajar siswa guru dituntut lebih kreatif dalam penggunaan media. Nurseto (2011: 19) mengungkapkan kegiatan pembelajaran menuntut dikuranginya metode ceramah dan diganti dengan pemakaian banyak media. Penggunaan media member peranan penting dalam pembelajaran terutama dalam mengendalikan perhatian siswa.

Berdasarkan hasil pre-test nilai rata-rata hasil belajar siswa yaitu 56,15 degan presentase kategori 38,46\% sangat rendah, 53,84\% rendah, 7,69\% sedang, $0,0 \%$ tinggi dan $0.0 \%$ sangat tinggi. Dari presentase tersebut dapat dikatakan bahwa tingkat kemampuan murid dalam memahami serta penguasaan kemampuan membaca sebelum digunakan media pembelajaran power point tergolong rendah.

Selanjutnya nilai rata-rata hasil post-test adalah 76,15 dengan presentase kategori sangat tinggi 38,36, tinggi $23,07 \%$, sedang $15,38 \%$, rendah 23,07 dan sangat rendah berada pada presentase $0,0 \%$. Melihat dari presentase tersebut dapat dikatakan bahwa tingkat kemampuan murid dalam memahami serta penguasaan materi keterampilan 
membaca tergolong tinggi setelah menggunakan media.

Adapun pun hasil belajar kemampuan membaca siswa Analisis statistik inferensial dengan menggunakan rumus uji $\mathrm{t}$, diketahui bahwa nilai $\mathrm{t}_{\text {hitung }}=$ 5,94. Dengan frekuensi (dk) sebesar 13 $1=12$, pada taraf signifikansi $0,05 \%$ diperoleh $t_{\text {tabel }}=2,178$ Oleh karena $t_{\text {hitung }}$ $>t_{\text {tabel }}$ pada taraf signifikansi 0,05 , maka hipotesis nol $\left(\mathrm{H}_{0}\right)$ ditolak dan hipotesis alternative $\left(\mathrm{H}_{1}\right)$ diterima yang berarti bahwa penggunaan powerpoint berpengaruh terhadap hasil belajar murid kelas IV SDN 03 Ele Kabupaten Barru.

Hasil pengujian ini sejalan dengan beberapa penelitian terdahulu diantaranya adalah hasil penelitian Khoirumattin (2011) dengan judul Pengaruh Penggunaan Media Pembelajaran Power Point terhadap Daya Tarik dan Prestasi Belajar PKN Siswa Kelas VII SMP Negeri di Sewon Bantul", dimana hasil yang telah dicapai dalam penelitian tersebut adalah ada pengaruh terhadap daya tarik dan prestasi belajar siswa dalam penggunaan media pembelajaran power point. Selain itu Pratiwi dalam skripsi yang berjudul
"Penggunaan Media Power Point terhadap Peningkatan Hasil Belajar Siswa pada Materi Bangun Ruang di Sekolah Dasar" tahun 2013 menyimpulkan terdapat peningkatan hasil belajar siswa dalam pembelajaran dengan menggunakan media power point pada materi bangun ruang dibandingkan pembelajaran konvensional.

Hasil belajar siswa dipengaruhi oleh beberapa faktor. Slameto (2002:57) mengungkapkan minat merupakan salah satu faktor yang mempengaruhi belajar. Minat besar pengaruhnya terhadap belajar, karena bila bahan pelajaran yang dipelajari tidak sesuai dengan minat siswa, siswa tidak akan belajar dengan sebaik-baiknya karena tidak ada daya tarik baginya. Siswa tidak semangat untuk belajar dan bahkan tidak ada kepuasan dari pelajaran yang diberikan. Bahan pelajaran yang menarik minat siswa, lebih mudah dipelajari dan disimpan karena minat menambah kegiatan belajar. Maka dari itu untuk membangkitkan minat belajar siswa, guru diharapkan mampu memberikan lebih kreatif dalam mengolah pembelajaran. Guru dapat memaksimalkan sarana pelajaran yang disiapkan sekolah dan membuat media 
sebagai salah satu penunjang belajar siswa.

Guru memerlukan media guna membantu dalam menyajikan dan memperjelas materi pelajaran, sehingga tercapai efektivitas dan efisiensi pembelajaran. Media juga merupakan salah satu yang dapat mempengaruhi hasil belajar. Media power point dapat dijadikan salah satu pilihan media pembelajaran karena memiliki banyak kelebihan. Power point memiliki fitur dan tampilan yang bervariatif sehingga dapat menarik perhatian siswa. Media power point juga menjadikan pembelajaran lebih terarah membuat siswa lebih dapat mengingat pembelajaran yang diberikan sehingga lebih memudahkan guru dalam menyampaikan pembelajaran. Hal ini dibuktikan dengan hasil penelitian dimana hasil belajar siswa lebih baik setelah menggunakan media power point daripada sebelum menggunakan media pembelajaran power point.

Dari hasil penelitian, hasil belajar yang lebih tingi setelah menggunakan media pembelajaran power point. Media pembelajaran power point digunakan menjadi pemicu minat belajar siswa. Besarnya minat belajar siswa juga berpengaruh terhadap hasil belajar siswa yang lebih tinggi.

\section{SIMPULAN DAN SARAN}

Berdasarkan hasil penelitian dan pembahasan disimpulkan bahwa ada pengaruh media pembelajaran power point terhadap minat belajar. Hal ini dibuktikan dengan hasil observasi yang tergolong tinggi yaitu 26,07 dengan presentase sebesar 84,61\%. Berdasarkan hasil uji hipotesis yang telah dilakukan dapat disimpulkan bahwa ada pengaruh penggunaan media pembelajaran power point terhadap hasil belajar kemampuan membaca siswa kelas IV SDN 03 Ele, Kabupaten Barru setelah diperoleh $t_{\text {Hitung }}=5,94$ dan $t_{\text {Tabel }}=$ 2,178 maka diperoleh $t_{\text {Hitung }}>t_{\text {Tabel }}$ atau 5,94 $>2,178$. Berdasarkan temuan yang berkaitan hasil penelitian penggunaan media pembelajaran power point yang mempengaruhi hasil belajar kemampuan membaca siswa kelas IV SDN 03 Ele Kabupaten Barru, maka dikemukakan beberapa saran sebagai berikut : (1) Kepada para pendidik khususnya guru-guru SDN 03 Ele Kabupaten Barru disarankan agar lebih banyak memberikan inovasi-inovasi dalam pembelajaran termasuk penggunaan media pembelajaran dan sarana pembelajaran yang variatif, seperti penggunaan media pembelajaran power point agar dapat 
meningkatkan minat dan motivasi siswa dalam belajar. (2) Kepada peneliti selanjutnya, penelitian ini dapat dijadikan bahan pertimbangan dan dapat melanjutkan penelitian dengan meneliti media pembelajaran. Selain itu, peneliti selanjutnya juga dapat mengembangkan penelitian ini, baik menggunakan media pembelajaran power point maupun media inovatif lainnya.

\section{DAFTAR PUSTAKA}

Ahsin. 2017. http://ahsinrifqy.blogspot.co.id/2 016/06/makalah-keterampilanmembaca.html [diakses pada tanggal 29/04/2017 pukul 14.06 Wita]

Anitah, Sri. 2008. Strategi Pembelajaran di $S D$. Jakarta: Universitas Terbuka.

Azhar, Arsyad. 2007. Media Pembelajaran. Jakarta: PT Raja Grafindo Persada.

Badan Standar Nasional Pendidikan. 2006. Panduan Penyusunan Kurikulum Tinkat Satuan Pendidikan. Jakarta: Depdiknas.

Dawud. 2008. Pembelajaran Membaca Pemahaman untuk Apresiasi Cerita di Sekolah Dasar. Malang: Sastra Indonesia. [online] tersedia; http//www.ksdpum.web.id/jurnal /Dawud.pdf. Akses Tanggal 06 Juni 2017

Departemen Pendidikan Nasional. 2003. Undang-undang Nomor 20 Tahun 2003. Tentang Sistem Pendidikan Nasional. Jakarta: Depdiknas.
Fakultas Keguruan dan Ilmu Pendidikan Unismuh Makassar. 2014. Pedoman Penulisan Skripsi. Makassar: FKIP Unismuh Makassar.

Hamalik, Oemar, 2001. Proses Belajar Mengajar. Jakarta: Bumi Aksara.

Hamalik, Oemar, 2007. Proses Belajar Mengajar. Jakarta: Bumi Aksara.

Khoirumattin, M. 2013. Pengaruh Penggunaan Media Pembelajaran Power Point terhadap Daya Tarik dan Prestasi Belajar PKN siswa Kelas VII SMP Negeri di Sewon Bantul. Thesis tidak diterbitkan. Yogyakarta: UNY.

Lestari, Desi Sri. 2011. Pengaruh Penggunaan Media Power Point Terhadap Hasil Belajar Siswa Kelas X SMA N 1 Depok tahun ajaran 2010/2011 pokok bahasan Jamur. Yogyakarta: Universitas Islam Negeri Sunan Kalijaga Yogyakarta

Nasution. 2006. Berbagai Pendekatan Dalam Proses Belajar Mengajar.Jakarta: Bumi Aksara.

Pratiwi, Anggun Asri.2013. Penggunaan Media Power Point terhadap Peningkatan Hasil Belajar Siswa pada Materi Bangun Ruang di Sekolah Dasar. Bandung: Universitas Pendidikan Indonesia.

Rianarwati, Dwi. 2006. Penggunaan Media Gambar dalam Pembelajaran untuk Meningkatkan Prestasi Belajar Pengetahuan Sosial Kelas IV SD Mangun Baru Wates Kulon Progo. 
Skripsitidak diterbitkan. Yogyakarta: UNY.

Rohani, Ahmad. 1997. Media Intruksional Edukatif. Jakarta: Rineka Cipta.

Rudi Susilana, Cepi Riyana. 2009. Media Pembelajaran. Bandung: Pustaka Pelajar.

Rusman. 2012. Belajar dan Pembelajaran Berbasis Komputer. Bandung: Alfabeta.

Sadiman Arief S. dkk. 2006. Media Pendidikan, Pengertian, Pengembangan, pemanfaatan. Jakarta: Pustekom Dikbud .

Saleh, Abbas. 2006. Pembelajaran Bahasa Indonesia yang Efektif di Sekolah Dasar. Jakarta: Departemen Pendidikan Nasional.

Sanaky, A. H Hujair. 2009. Media Pembelajaran. Safiria Insania Press.

Slameto. 2003. Belajar \& Faktor-faktor yang Mempengaruhi.Jakarta : PT. Rineka Cipta.

Sudjana, Nana. 2009. Penilaian Hasil Proses Belajar Mengajar. Bandung. PT Remaja Rosdakarya.

Sugihartono, dkk. 2007 Psikologi Pendidikan, Yogyakarta : UNY Press.

Sukardjo \& Ukim Komaruddin. 2013. Landasan Pendidikan. PT Raja Grafindo Persada.
Sunardi. 2017. Media Pembelajaran. http://lp3m.unimus.ac.id/wpcontent/uploads/2017/01/Sunard i-Tutorial-Media-Pembelajaran-dgpowerpoint.pdf [di akses pada tangggal 29/04/2017 pukul 11.33 Wita]

Suryabrata, Sumadi. 1988. Psikologi Pendidikan. Jakarta: Penerbit Bulan Bintang.

Syah, Muhibbin. 2009. Psikologi Belajar.Jakarta : PT Raja Grafindo Persada.

Trianto. 2010. Pengantar Penelitian bagi Pengembangan Pendidikan dan Tenaga Kependidikan. Jakarta: Kencana

Undang-undang Republik Indonesia No. 20 Tahun 2003. TentangSistemPendidikanNasional. Jakarta: Cemerlang. 